\title{
第38回総会会員研究発表抄録
}

\section{撮影-1 断層撮影}

座長 伊藤陸郎（福島医大）

\section{1. 密度と断層厚}

\author{
山口大学医学部附属病院放射線部 \\ ○岡山昭雄・迎 英紀・田中貞人 \\ 山内秀一 - 山下英昭 - 中西 敬
}

われわれはポリトームUの直線軌道を使用し，密度差 による断層愿の変化について CT 値より検討した。測定 方法はテストチャート（ポリエチレンチューブに造影剤 コンラキシンLの希釈液および空気を封入したものと針 金を使用）の撮影像から求める方法を用い，像の濃度之 素地濃度の差の半值幅を断層厚とし求めた。またポりエ チレンチューブの管壁の影響を防ぐため，乙れと同じ CT 值-102 になるイソプロピルアルコール $45.5 \%$ 液 (11 $\mathrm{cm}$ 厚) において行った。その結果次のような結論を得 た、断層擪は密度の低いものはど，素地濃度が高くなる ほどまた高電压になるほど薄くなる．陰コントラスト法 は陽コントラスト法に比し厚くなりその差は径が大きく なると小さくなる。

\section{2. 短時間断層撮影の意義}

$$
\begin{aligned}
& \text { 帝京大学医学部附属病院放射線科 } \\
& \text { O佐野芳知・中畑和朗・萩原充人 } \\
& \text { 鈴木 敦・小川儆寿 } \\
& \text { (株) 日立メディコ柏工場設計部 } \\
& \text { 舘外志雄 }
\end{aligned}
$$

〔目的〕成人の不随意運動を伴う蔵器の断層撮影には 短時間撮影が要求される.すでに小児用断層装置として $\mathrm{Ph}$ 社は $32^{\circ}, 0.08$ 秒機をまたH社は $30^{\circ}, 0.2$ 秒機を開発 し実用に供している。. 今回 $40^{\circ}, 0.5$ 秒，4分割全撮影を 10秒で可能な円弧式断層撮影装置を開発したので，成人 胸腹部臓器に対する短時間断層撮影の臨木的意義につい て報告する。

〔結果および考察】分割撮影時間 ( 2 分割 4 秒, 4 分 割10秒) が短いため, 肺野, 胆道系, 䀦頭等は一呼吸で 撮影できるととから，截断面間の間隔は明らかに定値を 示し，呼吸量による層間の均等性が失われないなど極め て意義ある例が多い。

\section{3. 内耳断層撮影において基準面の変化による各層の部 位現出率の統計的検討}

弘前大学医学部附属病院放射線部

○斎藤 隆・金沢隆太郎・藤森 明 小山桂一・長内恒美・木村 均 工藤亮裕・安倍勝美 $\cdot$ 石田 晃 樽沢 清 - 坂本哲太・柴田俊雄 上田隆三 弘前大学医療短大放射線技術学科 樽沢孝悦

現在まで一般的に行なわれている内耳前額面断層撮影 は, 外耳孔を基準に前後 $2 \mathrm{~mm}$ 毎10枚撮影する方法が主 である.この撮影法では，截断面の基準と内耳の現出率 の関係や撮影する層の適正な截断の範用が不明確であっ た. そとでわれわれは，乙れらの関係について，臨床写 真 200 例から統計的に解明し, 内耳の現出率を得た.

外耳孔後壁を基準に $2 \mathrm{~mm}$ 毎 5 層の増感紙を用い, 8 $\mathrm{mm}$ 顔面側を 1 層目として撮影すると $74 \%$ の耳の現出 率を得，さらに 7 層では $86 \% ， 9$ 層では99\%の内耳の現 出率を得ることがわかった．乙のように統計的に内耳の 検出率を調べることにより，従来からの撮影に比べて， より確実な内耳額面断層撮影が可能になった。

\section{4. 三叉神経ブロックにおける断層撮影の適用}

医療法人医人会中村記念病院

○宮本和昭・高橋正昭 山岸 仁・佐藤勝保

三叉神経ブロックにおけて，上頢部から経皮的に刺入 したブロック針を適正位置に進入させるため，X線写真 による確認が行なわれている。

しかし，乙の方法だけで針先の位置確認をするには確 実性に欠ける.

そこでわれわれは断層撮影を施行し，針先の位置確認 をさらに明確にした。

とれによりブロック針を三叉神経節に進入させること を正確，かつ容易にした。

さらに，合併症を防止し治療效果毛商めた。

\section{座長集約}

総会での発表は，ポピュラーな分野に演題数が集中す るのは止むを得ないととで，断層撮影についても，多軌 道方式装置の一斉出現の頃の演題数加ら見ると CT, 超 音波によって代られた感がある，そんな中で，従来，論 じられて来た分野にでも，さらにもう一度検討を加えて 
いとうとしている方々に敬意を表する。

本年の, このセッションでの演題は, 断層撮影の理論 があっている層の厚みについて検討したものが1題, 臨 床応用についての報告が 3 題の計 4 題にとどまった。

第 1 席，密度と断層厚については，過去，本学会ある いは，断層撮影法研究会でも，幾度か取りあげられたも のである、演者等は，過去の発表者が wire，air 等，限 定的材料であったのを CT 値の異なる吸収体を用いる事 で臨床に近ずけようとしている. しかし，X線写真上に 現われる被写体の厭みは, 密度のほか, 大きさ, 振り角, 斜入によるボケ，周囲の濃度等の要因が多く一枚の断層 写真は, 場所によって擪さの異なる凹山像になっている から数類的な判断は難かしい：演題 $273 \sim 275$ と同じグル 一プで討論された方が良いと思った。いっそう臨床と対 此された結果を期待したい.

第 2 席は, ばく射時間と断層像について述べている. 多軌道断層によって，障憲陰影の除去については，ある 程度効果があったが，被写体の運動によるボケ因子が大 きい. 短時間撮影によって画質が向上しており，胸郭内 での末梢部位の検索に威力を発揮するであろう。

第 3 席は, 内耳断層写真の至適な層数あるいは範囲を 決定するための統計的な調査の報告である. 解剖学的に は $10 \mathrm{~mm}$ の範囲に入る位の大きさであるから $16 \mathrm{~mm} の$ 間に分布するのは，ポジショニングに問題があるのでは との助言（帝京大・小川）があったが，錘体の前下方に 位置する蝸牛部と, 後上方にある内耳道, 半規管の描写 は，どちらむ両外耳口を結ぶ線よりは頭頂側にあるので， ドイツ水平線を垂淔にする場合と $\mathrm{OM}$ 線を重淔にする 場合では示現の範囲は異なる。䇥者は両者を 1 ～層で 描出する体位を試みたが，患者の固定が容䀛でなかった。 ルチンの検査では，患者の体位固定が容易であることも 1 つの要素であるから，あまり範囲をせばめず乳様部ま で観察する事も必要ではなりかと思う：

第 4 席は，三文神経ブロック処置時に注射針の位置確 認に断層写真を利用している報告である.乙の処置法は 麻酔医によって一般に行なわれているが熟練を要するて となので，透視，立体撮影等とこもに断層撮影屯効果的 である。

断層撮影での軌道と部位については，一応の成果はで き上っているが, 厚さ, 密度の計測, 障害陰影の除去等 まだまだ研究されねばならない.ディジタルオシオグラ フィの普及等で, より発展の機会のあることに期待して いる。

\section{撮影-2 間接撮影他}

座長 怌々朴仙悦（岩手医大）

\section{X線映画撮影における拡大撮影について}

国立循環器病センタ一放射線診祢部

○田中 勲・若松孝司・岡 尚喟

従来X線シネ撮影においてX線写真像のボケを小さく して鮮鋭な像を作るため可能な限り I.I. を被写体に近付 けて撮影したが，被写体面における総合レスポンスは， 拡大倍率が増加するに従ってよくなっている．また実際 の臨床においては，散乱線の影響は大きいが，I.I. 面よ り $40 \mathrm{~cm}$ 程度の距離をとれば, グレーデル効果により改 善される. 今回，乳幼児・小児撮影飞拡大撮影を行なっ たが, I.I. 視野の有効的利用, 微細構造の見やすさ, 被 曝線量低減などの点より, 管球焦点 $0.6 \mathrm{~mm}$ においても, グレーデル效果を利用した, X線シネ広大撮影は, 有意 義な写真像が得られた。

\section{6. 気管軟化症における気管動態撮影について}

京都桂病院 ○田辺正和・本郷隆治 石井良和・小倉佐助

〔目的〕われわれは, 気管・気管支の原因不明な気道 支持組織の脆弱化によって起乙る後天性気管軟化症の状 態を知るために，気管動態撮影を行なって確定診断の一 助としている.

〔結果】乙の撮影法は, 気管支鏡検査の結果との相関 む高く，呼気時に気管・気管支軟骨輪の膜様部が気道内。 腔に向って互いに近接し強く陥凹するのが，造影剤を用 いなくても，患者に咳をさせるだけの簡単な協力で正確 に把握し得る方法であり，気管支喘息などとの鑑別は非 常にたやすくなるため最も有用な検査方法であると考え られる。

\section{7. 間接撮影による気管支造影の試み}

国家公務員共済組織連合会 虎の門病院中央放射線部

○広瀬一男・勝又清一・菊地貞吉 細矢志郎・阿部二夫

メタル I.I.(12", 9," 6" 視野切換型) と $0.1 \mathrm{~mm} / 0.6 \mathrm{~mm}$ 焦点の組み合わせよる，X線拡大機構付き透視撮影装置 で; 気管支造影の間接撮影（I.I. 拡大，X線拡大）を試 み，同一装置での直接写真と比較した.アンダーチュー ブ型透視撮影台で，乙れを行なう時，フィルムと目的部 が離れてしまい側方向の時は特にその傾向が著しい。こ れは直接撮影の時は鮮鋭度が低下するという久点となる が, I.I. 間接の場合は高感度という特質を $0.1 \mathrm{~mm}$ 焦点 